\title{
Practical way of creating differential diagnoses through an expanded VITAMINSABCDEK mnemonic
}

\section{Zabidi A Zabidi-Hussin \\ Department of Paediatrics, School of Medical Sciences, Universiti Sains Malaysia, Kelantan, Malaysia}

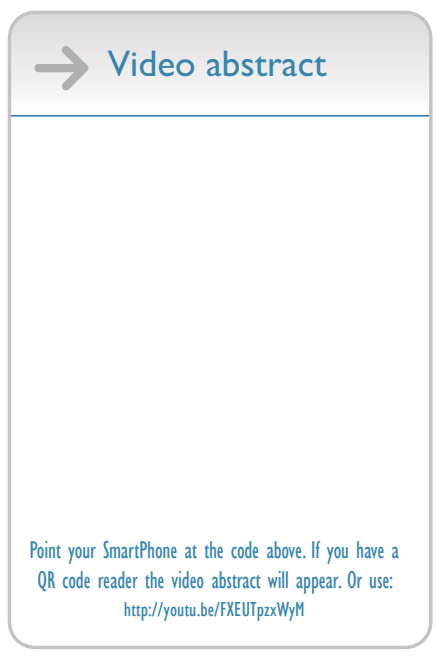

Correspondence: Zabidi A Zabidi-Hussin Department of Paediatrics,

School of Medical Sciences, Universiti Sains Malaysia, Health Campus, Kubang Kerian, Kelantan 16150, Malaysia Email zabidihussin@usm.my
This article was published in the following Dove Press journal:

Advances in Medical Education and Practice

22 April 2016

Number of times this article has been viewed

\begin{abstract}
Having an organized, structured thinking process is critical in medicine. It is through this thinking process that enables one to go through the method of history-taking, which will eventually lead to making a definitive diagnosis and all other processes that follow. The use of mnemonic has been found to be useful for this purpose. The mnemonic VITAMINSABCDEK, is a convenient and practical way to assist in expanding the differential diagnoses and covers all possible causes of an illness. It is also easy to remember, as the vitamins whose letters are represented in this mnemonic cover the entire range of vitamins known.
\end{abstract}

Keywords: mnemonic, differential diagnosis

\section{Discussion}

Making a definitive diagnosis is the main aim of history taking in medicine. However, the process of doing this may be difficult if a student has to remember all the symptoms of medical conditions without having a structured thinking process. The art of structured thinking is an essential part of analytical process in education. A student who is equipped with this structure will be able to expand his/her scope of differential diagnoses in medicine, in a logical and comprehensive manner. The use of "mnemonic" is not new in medicine. The mnemonic VITAMINCDE as an aid memoire in making differential diagnosis is seen in the Family Medicine Reference web site. ${ }^{1}$ An expansion of this mnemonic will serve to cover many more medical conditions. This new and expanded mnemonic takes into consideration all possible causes of diseases for the purpose of formulating a diagnosis and instituting clinical management plan. The aim of this mnemonic is to approach diseases from their etiologies and not from anatomical perspectives. I propose the expansion of VITAMINSABCDEK to complement the existing mnemonic. "V" stands for "vascular", where the disease can be caused by "vessel" (bleed or blocked), or anything related to hematology. "I" is for "infective" or "post infective" causes. "T" is for "trauma" or anything caused by mechanical factors such as obstructions or pressure. "A" is for causes of "autoimmune"-related illnesses or "allergy". "M" is for "metabolic" causes affecting lipids, proteins, carbohydrates, or micronutrients. "I" is for "idiopathic" or "iatrogenic" causes. "N" is for "neoplasia". "S" is for diseases caused by "social" reasons, such as child abuse and social deprivation. " $\mathrm{A}$ " is for diseases caused by "alcohol"-related issues. " $\mathrm{B}$ " is for diseases caused by "behavioral" or psychosomatic disorders. "C" is for diseases caused by "congenital" problems (the entire VITAMINSABCDEK could be applied again in the congenital causes). " $\mathrm{D}$ " is for diseases caused by "degenerative" disor- 
ders or "drug"-related problems. "E" is for diseases caused by "endocrine" or "exocrine" problems. The last letter "K" would serve a reminder to diseases caused by "karyotype" or genetic disorders. Application of this simple mnemonic to the history-taking process would serve to expand the scope of differential diagnoses and lead to a more accurate management of a patient.

\section{Disclosure}

The author reports no conflicts of interest in this work.

\section{Reference}

1. Family Medicine Reference [webpage on the Internet]. Differential Diagnosis - VITAMIN CDE. Available from: http://www.fammedref. org/mnemonic/differential-diagnosis-vitamin-cde. Accessed February 16,2016 .

\section{Publish your work in this journal}

Advances in Medical Education and Practice is an international, peerreviewed, open access journal that aims to present and publish research on Medical Education covering medical, dental, nursing and allied health care professional education. The journal covers undergraduate education, postgraduate training and continuing medical education including emerging trends and innovative models linking education, research, and health care services. The manuscript management system is completely online and includes a very quick and fair peer-review system. Visit http://www.dovepress.com/testimonials.php to read real quotes from published authors.

\footnotetext{
Submit your manuscript here: http://www.dovepress.com/advances-in-medical-education-and-practice-journal
} 